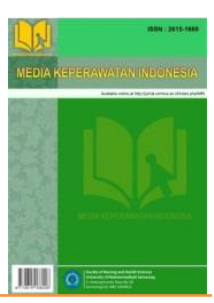

Research article

\title{
Risk Factors of Stunting in Children Age 24-59 Months Old
}

\section{La Ode Alifariki ${ }^{1}$, La rangki ${ }^{2}$, Haryati Haryati ${ }^{3}$, Rahmawati Rahmawati ${ }^{4}$, Sukurni $^{2}$ Sukurni5, Wa Ode Salma ${ }^{6}$}

${ }^{1}$ Departemen Epidemiologi, Fakultas Kedokteran, Universitas Halu Oleo

2,3,4,5 Departemen Keperawatan, Fakultas Kedokteran Universitas Halu Oleo

${ }^{6}$ Departemen Ilmu Gizi, Fakultas Kesehatan Masyarakat Universitas Halu Oleo

\section{Article Info}

\section{Article History:}

Accepted 19 January 2020

\section{Keywords:}

Risk Factor; Stunting Events

\begin{abstract}
Stunting is a short and very short body state that exceeds the Z-Score -2 SD deficit below the median length or height, as measured by height by age or length by age (TB / U or PB / U). Many factors affect the incidence of stunting in toddlers aged 24-59 months. The aim of the study is to determine the determinants of the incidence of stunting in infants aged 24-59 months. This type of research is observational analytic using a case-control design. The study population was all mothers who have children aged 24-59 months in the working area of Puuwatu Health Center, Kendari City. The number of sample cases as many as 35 people while the number of control samples as many as 72 people with a sample comparison of 1 case: 2 controls so that the total sample size of 108 people, obtained through purposive sampling. The results showed that mothers who had a height of $<150 \mathrm{~cm}$ had a risk of 2.6 times having a toddler suffering from stunting compared to mothers who had a height of $\geq 150 \mathrm{~cm}$. Determinants of stunting proxies in the working area of Puuwatu Health Center, Kendari City was maternal height with Exp value $=0.386$.
\end{abstract}

\section{PENDAHULUAN}

Masalah gizi merupakan hal yang sangat kompleks dan penting untuk segera diatasi, terutama karena indonesia merupakan salah satu negara yang mempunyai permasalahan gizi paling lengkap seperti anemia (kekurangan zat besi), Kekurangan Energi Kronis (KEK), obesitas (kegemukan) dan Stunting (pendek)(UNICEF, 2015). Stunting merupakan kelainan atau kegagalan pertumbuhan linear terjadi pada anak kecil yang menandai gangguan patologis dan kondisi kronis (Indriyan, DewI, \& Salimo, 2018 ; Budge, Parker,
Hutchings, \& Garbutt, 2019). Indikator stunting adalah keadaan tubuh pendek dan sangat pendek hingga melampaui defisit ZScore -2 SD di bawah median panjang atau tinggi badan, yang diukur dengan tinggi badan menurut umur atau panjang badan menurut umur (TB/U atau $\mathrm{PB} / \mathrm{U})$, dengan ciri postur anak lebih pendek dari anak seusianya, berat badan rendah untuk anak seusiannya dan pertumbuhan tulang tertunda (Kemenkes RI, 2017).

Dampak balita yang mengalami stunting meningkatkan risiko penurunan kemampuan intelektual, menghambatnya

Corresponding author:

La Ode Alifariki

ners_riki@yahoo.co.id

Media Keperawatan Indonesia, Vol 3 No 1, Februari 2020

e-ISSN: 2615-1669

DOI: https://doi.org/10.26714/mki.3.1.2020.10-16 
kemampuan motorik, produktivitas, dan peningkatan risiko penyakit degeneratif di masa mendatang (Astari L D, Nasoetion A, 2015). Efek kumulatif dari kerusakan yang diakibatkan oleh perkembangan kognitif dan fisik balita stunting adalah penurunan kapasitas produktif termasuk prestasi sekolah yang lebih rendah, pengeluaran per kapita rumah tangga yang lebih rendah, dan penurunan output ekonomi nasional (Black et al., 2013). Ukuran kerugian perkembangan akibat stunting diperkirakan bahwa dalam satu tahun, individu stunting akan mendapatkan ratarata $22 \%$ penurunan perkembangan dibanding individu non stunting dan laporan Bank Dunia memperkirakan pembiayaan akibat stunting dapat mengurangi $3 \%$ produk domestik bruto suatu Negara (Onis \& Branca, 2016).

Angka kejadian stunting di dunia masih cukup tinggi. Ada 178 juta anak di dunia yang terlalu pendek berdasarkan usia dibandingkan dengan pertumbuhan standar WHO. Prevalensi anak stunting di seluruh dunia adalah $28,5 \%$ dan di seluruh negara berkembang sebesar 31,2\%. Prevalensi anak stunting dibenua Asia sebesar 30,6\% dan di Asia Tenggara sebesar 29,4\% (UNICEF, 2013).

Hasil Riset Kesehatan Dasar pada tahun 2013 diketahui bahwa prevalensi kejadian stunting secara nasional adalah $37,2 \%$, dimana terdiri dari 18,0\% sangat pendek dan 19,2 \% pendek, yang berarti telah terjadi peningkatan sebanyak $1,6 \%$ pada tahun 2010 (35,6\%) dan tahun 2007 (36,8\%) dan hasil Riset Kesehatan Nasional 2018 menunjukkan adanya pebaikan status gizi pada balita di Indonesia. Proporsi status gizi sangat pendek dan pendek turun dari 37,2\% menjadi 30,8\%(Kemenkes RI, 2018). Provinsi Sulawesi Tenggara pada tahun 2007 prevalensi stunting mengalami peningkatan sebesar $33,4 \%$, pada tahun 2010 mengalami penurunan sebesar $28,3 \%$, dan mengalami peningkatan kembali pada tahun 2013 sebesar 31,7\% dan naik pada tahun 2018 menjadi 36\% (Dinkes, 2016).
Data Dinas Kesehatan Kota Kendari menunjukkan Prevalensi stunting pada tahun 2010 sebesar 421 per 10.000 balita. Pada tahun 2012 sebesar 908 per 10.000 balita. 2 Pada tahun 2014 sebesar 2.162 per 10.000 balita. Menurut Laporan Pemantauan Status Gizi Balita pada tahun 2016, status gizi balita yaitu sangat pendek sebesar 8,6\%, pendek sebesar 20,0\% dan normal sebesar 71,4\% (Dinkes, 2016). Hasil penelitian lain menunjukkan bahwa faktor risiko kejadian stunting adalah BBLR, riwayat pemberian ASI ekslusif, riwayat pemberian MP-ASI, riwayat ASI Eksklusif, riwayat usia pemberian MP-ASI dan tinggi badan ibu (Jihad \& Ainurafiq, 2016).

Puskesmas Puuwatu merupakan salah satu Puskesmas dengan kasus gizi kurang tertinggi pada tahun 2015 yaitu sebesar 1,1\% sementara Puskesmas Benu-benua dan Puskesmas Labibia masing-masing sebesar 2,5\%. Data Puskesmas Puuwatu, tentang kejadian stunting balita usia 24-59 bulan tahun 2012 terdapat 3,1\% kasus, pada tahun 2013 terdapat 2,6\% kasus, pada tahun 2014 terdapat 7,6\% kasus, kemudian pada tahun 2015 terdapat 9,7\% kasus, meningkat pada tahun 2016 menjadi 9,9\% dan tahun 2017 menjadi $10,1 \%$ dan menurun pada tahun 2018 menjadi 8,9\% (Puskesmas Puuwatu, 2017). Tujuan penelitian ini adalah untuk mengetahui faktor resiko kejadian stunting pada balita usia 24-59 bulan.

\section{METODE}

Penelitian merupakan penelitian kuantitatif analitik dengan pendekatan case-control. Penelitian ini menganalisis faktor paparan yang mungkin memengaruhi terjadinya stunting. Responden dalam penelitian ini adalah ibu yang mempunyai balita usia 2459 bulan di wilayah kerja Puskesmas Puuwatu, sejumlah 108 yang terdiri dari 36 sampel kasus dan 72 sampel kontrol yang dihitung menggunakan rumus Lemeshow.

Pengumpulan data menggunakan kuesioner dengan responden kasus dan kontrol. Data 
diolah dengan program SPSS, penyajian data dalam bentuk tabel dan narasi berdasarkan variabel yang diteliti. Data dianalisis secara deskriptif (univariat) dan bivariat menggunakan (OR) dan uji multivariate menggunakan logistic regresi pada batas kemaknaan $\mathrm{a}=0,05$.

\section{HASIL}

Hasil penelitian menunjukkan bahwa kejadian stunting pada kelompok kasus lebih banyak usia ibu 30-34 tahun sebanyak $58,4 \%$. Tingkat pendidikan pada kelompok kasus lebih didominasi pendidikan SMP, sedangkan kelompok kontrol didominasi tingkat Pendidikan SMA. Jenis pekerjaan yang paling banyak pada kedua kelompok adalah ibu rumah tangga, kasus sebanyak $58,4 \%$ dan kontrol sebanyak 45,8\%.

Variabel prediktor/independen, terlihat bahwa faktor risiko tinggi badan terhadap kejadian stunting pada kelompok kasus paling banyak kategori $\leq 150 \mathrm{~cm}$ sebanyak 20 orang $(55,6 \%)$ sedangkan pada kelompok kontrol paling banyak pada kategori > $150 \mathrm{~cm}$ sebanyak 49 orang $(68,1 \%)$ dengan nilai OR sebesar 2,6 $(1,169$ 6,066), artinya bahwa ibu yang memiliki tinggi badan $<150 \mathrm{~cm}$ berisiko sebesar 2,6 kali memiliki balita menderita stunting dibanding ibu yang memiliki tinggi badan $\geq$ $150 \mathrm{~cm}$. Faktor risiko frekuensi ANC terhadap kejadian stunting pada kelompok kasus paling banyak kategori $\geq 4$ kali sebanyak 25 orang $(69,4 \%)$ sedangkan pada kelompok kontrol paling banyak pada kategori < 4 kali sebanyak 60 orang $(83,3 \%)$ dengan nilai OR sebesar 2,2 $(0,858-5,642)$. Faktor risiko riwayat ASI ekslusif terhadap kejadian stunting pada kelompok kasus paling banyak kategori ya sebanyak 19 orang $(52,8 \%)$ sedangkan pada kelompok kontrol paling banyak pada kategori ya sebanyak 56 orang $(77,8 \%)$ dengan nilai OR sebesar 3,1 (1,327-7,389). Ibu yang memiliki riwayat pemberian ASI tidak ekslusif berisiko sebesar 3,1 kali memiliki balita stunting dibanding ibu yang memberikan ASI esklusif. Faktor risiko pendapatan keluarga terhadap kejadian stunting pada kelompok kasus paling banyak kategori < Rp. 2.177.052 sebanyak 23 orang $(63,9 \%)$ sedangkan pada kelompok kontrol paling banyak pada kategori $\geq$ Rp. 2.177.052 sebanyak 39 orang $(54,2 \%)$ dengan nilai OR sebesar 2,1 (0,9184,762). Artinya bahwa keluarga berpendapatan rendah < Rp.2.177.052 berisiko sebesar 2,1 memiliki balita stunting dibanding keluarga berpendapatan tinggi.

Hasil analisis multivariat menunjukkan nilai Exponensial yang paling besar adalah tinggi badan. Hal ini menunjukkan bahwa dari 4 variabel predictor/dependen yang diproses pada analisis multivariate dan paling besar pengaruhnya terhadap kejadian stunting di Wilayah kerja Puskesmas Puuwatu Kota Kendari adalah tinggi badan ibu dengan nilai $\operatorname{Exp}=0,386$. 
Tabel 1

Analisis Risiko Kejadian Stunting di Wilayah Kerja Puskesmas Puuwatu

\begin{tabular}{|c|c|c|c|c|c|c|c|}
\hline \multirow[t]{3}{*}{ Indikator } & \multicolumn{4}{|c|}{ Kejadian Stunting } & \multicolumn{2}{|c|}{ Jumlah } & \multirow{3}{*}{$\begin{array}{c}\text { OR } \\
\text { CI } 95 \% \\
\end{array}$} \\
\hline & \multicolumn{2}{|c|}{ Kasus } & \multicolumn{2}{|c|}{ Kontrol } & & & \\
\hline & $\mathrm{n}$ & $\%$ & $\mathrm{n}$ & $\%$ & $\mathrm{n}$ & $\%$ & \\
\hline Tinggi Badan & & & & & & & 2,6 \\
\hline$\leq 150 \mathrm{~cm}$ & 20 & 55,6 & 23 & 31,9 & 43 & 39,8 & $(1,169-6,066)$ \\
\hline$>150 \mathrm{~cm}$ & 15 & 44,4 & 49 & 68,1 & 65 & 60,2 & \\
\hline Frekuensi ANC & & & & & & & 2,2 \\
\hline$<4$ kali & 11 & 30,6 & 12 & 16,7 & 23 & 21,3 & $(0,858-5,642)$ \\
\hline$\geq 4$ kali & 25 & 69,4 & 60 & 83,3 & 85 & 78,7 & \\
\hline Riwayat ASI ekslusif & & & & & & & 3,1 \\
\hline Tidak & 17 & 47,2 & 16 & 22,2 & 33 & 30,6 & $(1,327-7,389)$ \\
\hline Ya & 19 & 52,8 & 56 & 77,8 & 75 & 69,4 & \\
\hline Pendapatan keluarga & & & & & & & 2,1 \\
\hline < Rp. 2.177.052 & 23 & 63,9 & 33 & 45,8 & 56 & 51,9 & $(0,918-4,762)$ \\
\hline$\geq$ Rp. 2.177 .052 & 13 & 36,1 & 39 & 54,2 & 52 & 48,1 & \\
\hline
\end{tabular}

Tabel 2

Analisis multivariat

\begin{tabular}{|c|c|c|c|c|c|c|}
\hline \multirow[t]{2}{*}{ Variabel } & \multirow[t]{2}{*}{ B } & \multirow[t]{2}{*}{ S.E } & \multirow[t]{2}{*}{ Sig. } & \multirow[t]{2}{*}{$\operatorname{Exp}(B)$} & \multicolumn{2}{|c|}{ CI 95\% } \\
\hline & & & & & Lower & Upper \\
\hline Tinggi badan & -.951 & .452 & .035 & .386 & .159 & .937 \\
\hline Frekuensi ANC & -1.230 & .566 & .030 & .292 & .097 & .886 \\
\hline Riwayat ASI ekslusif & -1.098 & .467 & .019 & .334 & .134 & .833 \\
\hline Pendapatan keluarga & -1.138 & .502 & .023 & .320 & .120 & .858 \\
\hline Constant & 2.416 & .547 & .000 & 11.202 & & \\
\hline
\end{tabular}

\section{PEMBAHASAN}

Pada karakteristik tingkat pendidikan tingkat pendidikan, terlihat bahwa rata-rata ibu yang memiliki balita stunting baik pada kelompok kasus maupun kontrol, dominan berpendidikan sekolah menengah. Pendidikan ibu sendiri merupakan hal dasar yang dapat membantu tercapainya gizi anak yang baik. Apabila tingkat pendidikan ibu tinggi, maka akan lebih mudah untuk menerima informasi dibandingkan dengan ibu yang tingkat pendidikannya rendah. Dalam penelitian ini, ibu yang memiliki tingkat pendidikan rendah tidak selalu mengalami anak dengan masalah stunting dan begipula ibu dengan tingkat pendidikan tinggi pun masih memiliki balita stunting yakni ada $16,7 \%$.

Kejadian stunting pada kelompok kasus lebih banyak jenis pekerjaan sebagai ibu rumah tangga, demikian pada kelompok kontrol jenis pekerjaan terbanyak sebagai ibu rumah tangga. Proporsi pekerjaan ibu sebagai ibu rumah tangga atau tidak bekerja sebesar $54,8 \%$ memiliki balita stunting dibandingkan dengan ibu yang bekerja. Penelitian lain menjelaskan bahwa pekerjaan ayah dan ibu merupakan faktor risiko terjadinya stunting (Warsini et al, 2016). Hal ini sejalan dengan penelitian lain yang menyatakan bahwa ibu yang memiliki tinggi $<150 \mathrm{~cm}$ terdapat pada anak yang mengalami stunting. Penelitian lain yang mendukung yaitu penelitian yang dilakukan oleh Kartikawati (Kartikawati, 2011) yang menyatakan bahwa faktor genetik pada ibu yaitu tinggi badan berpengaruh terhadap kejadian stunting pada anak balita. Penelitian lain menjelaskan bahwa orangtua yang pendek karena adanya gen pembawa sifat pendek memiliki kemungkinan memiliki anak stunting (Mamabolo et al, 2014).

Faktor genetik dapat memengaruhi terjadinya stunting karena aliran darah rahim dan pertumbuhan uterus, plasenta dan janin pada ibu hamil pendek terbatas sehingga bayi yang dilahirkan memiliki berat badan rendah, sehingga perlu 
dilakukan perbaikan terhadap terjadinya perlambatan atau retardasi pertumbuhan janin yang dikenal sebagai IUGR (Intra Uterine Growth Retardation) dan berat bayi lahir rendah (BBLR). Kejadian ini akan berlangsung di generasi selanjutnya, masalah anak pendek antar generasi tidak bisa dihindari kecuali ada erbaikan gizi dan pelayanan kesehatan yang memadai pada masa-masa tersebut.

Hasil penelitian ini menunjukkan bahwa ada ibu pendek akan tetapi memiliki balita tidak stunting, hal ini diyakini bahwa jika tinggi badan pendek yang dimiliki ibu disebabkan karena masalah kurangnya pemenuhan gizi dan bukan masalah genetik. Sejalan dengan hasil penelitian lain yang menyatakan bahwa apabila orang tua pendek tersebut akibat karena ada faktor masalah gizi yang dialami orang tua maka belum tentu memiliki anak pendek sehingga ibu pendek tidak memiliki berpengaruh terhadap tinggi badan anaknya. Hal ini sejalan dengan penelitian lain yang menunjukkan bahwa kunjungan pemeriksaan kehamilan / antenatal care (ANC) tidak terstandar kemungkinan memiliki risiko 2,1 kali lebih banyak mengalami kejadian stunting daripada yang tidak stunting pada balita usia 12-59 bulan dengan mengikutsertakan variabel usia ibu saat hamil, pendapatan keluarga, berat badan lahir dan panjang badan lahir (pvalue < 0,05 dan OR 2,13; CI 95\% 1,0124,494) (Amin \& Julia, 2016). Penelitian lain menjelaskan bahwa ibu yang melakukan kunjungan pemeriksaan kehamilan / antenatal care (ANC) tidak standar memiliki risiko mempunyai balita stunting 2,4 kali dibandingkan ibu yang melakukan kunjungan pemeriksaan kehamilan / antenatal care (ANC) terstandar (Najahah, 2013).

Kunjungan pemeriksaan kehamilan / antenatal care (ANC) selama kehamilan yang dilakukan oleh seorang ibu secara teratur dapat mendeteksi dini risiko kehamilan terutama yang berkaitan dengan masalah nutrisinya. Setiap kehamilan dalam perkembangannya memiliki risiko mengalami komplikasi/penyulit. Sehingga sesuai standar, pemeriksaan kehamilan / antenatal care (ANC) harus dilakukan secara rutin agar mendapatkan pelayanan antenatal yang berkualitas sehingga risiko seperti kekurangan gizi sejak hamil dapat dicari solusi sehingga tidak berdampak pada status gizi anak yang dikandungnya.

Masalah yang sering terjadi pada kehamilan yaitu komplikasi kehamilan. Keadaan seperti ini dapat diketahui secara dini dengan melakukan pemeriksaan kehamilan minimal 4 kali yaitu 1 kali pada trimester pertama, 1 kali pada trimester kedua dan 2 kali pada trimester ketiga (Alifariki L, Rangki, 2019).

ASI eksklusif penting mencegah stunting dan kegemukan pada anak-anak. Menyusui mengurangi risiko diare empat hingga enam kali lipat dan risiko penyakit pernapasan lima kali lipat (Erwin A, 2013). Pada penelitian ini diperoleh hasil riwayat ASI eksklusif berpengaruh terhadap kejadian stunting pada balita usia 24-59 bulan.

Hasil penelitian ini berbeda dengan beberapa penelitian sebelumnya diantaranya, penelitian lain yang menjelaskan bahwa tidak ada hubungan antara pemberian ASI Eksklusif dengan stunting pada anak batita, penelitian tersebut menjelaskan bahwa bayi yang tidak mendapat ASI eksklusif mempunyai kemungkinan risiko 2 kali untuk terjadi stunting (Rambitan et al., 2014). Hasil penelitian lain menjelaskan bahwa pemberian ASI eksklusif tidak berhubungan dengan kejadian stunting pada usia 6-12 bulan dengan $p$ value $0,269(\mathrm{p}>0.05)$ (Lestari, 2011).

Adanya perbedaan hasil penelitian ini karena pada penelitian ini jumlah kontrol yang digunakan dua kali lipat dari jumlah kasus sehingga hal ini memengaruhi hasil analisis statistik. Secara deskriptif terlihat bahwa baik pada ibu yang memiliki balita stunting maupun tidak stunting, riwayat pemberian ASI ekslusif menunjukkan angka 
yang tinggi yakni pada kasus sebesar 52,8\% dan pada kontrol sebesar 77,8\%, sehingga menurut keyakinan peneliti penyebab dari adanya risiko stunting dari riwayat pemberian ASI ekslusif disebabkan karena banyaknya sampel kontrol pada penelitian ini.

Penelitian lain menjelaskan bahwa anak balita yang hidup bersama keluarga dengan pendapatan keluarga yang rendah lebih berisiko terjadi stunting (Chirande et al., 2015). Pendapatan keluarga akan menentukan daya beli terhadap pangan dan beberapa fasilitas seperti pendidikan, perumahan, kesehatan, dan lain-lain yang dapat memengaruhi status gizi (Kurniasari, 2012). Pendapatan keluarga yang rendah, kualitas dan kuantitas bahan pangan yang dibeli juga akan rendah, sehingga dapat menyebabkan tidak terpenuhinya kebutuhan zat gizi dalam keluarga(Warsini, 2014).

Pada penelitian ini jelas bahwa ketika keempat variabel prediksi diuji secara bersama-sama maka nilai variabel riwayat pemberian ASI ekslusif tereduksi oleh variabel tinggi badan ibu.

\section{SIMPULAN}

Faktor resiko kejadian stunting di Wilayah kerja Puskesmas Puuwatu Kota Kendari adalah tinggi badan ibu dengan nilai Exp = 0,386 .

\section{UCAPAN TERIMAKASIH}

Melalui kesempatan ini, penulis ucapkan terima kasih kepada Bapak Rektor cq. Ketua LPPM Universitas Halu Oleo yang telah memberikan kesempatan kepada penulis untuk melakukan penelitian.

\section{REFERENSI}

Alifariki L, Rangki, K. A. (2019). Faktor determinan proksi kejadian kematian neonatus di wilayah kerja Dinas Kesehatan Kabupaten Buton Utara. Berita Kedokteran Masyarakat, 35(4), 131-138.
Amin, N. A., \& Julia, M. (2016). Faktor sosiodemografi dan tinggi badan orang tua serta hubungannya dengan kejadian stunting pada balita usia 6-23 bulan. Jurnal Gizi Dan Dietetik Indonesia (Indonesian Journal of Nutrition and Dietetics), 2(3),

170. https://doi.org/10.21927/ijnd.2014.2(3).170177

Astari L D, Nasoetion A, D. C. M. (2015). Hubungan Karakteristik Keluarga, Pola Pengasuh Dan Kejadian Stunting Anak Usia 6-12 Bulan. 29(2), 40-46.

Black, R. E., Victora, C. G., Walker, S. P., Bhutta, Z. A., Christian, P., De Onis, M., ... Martorell, R. (2013). Maternal and child undernutrition and overweight in low-income and middle-income countries. The Lancet, 382(9890), 427-451.

Budge, S., Parker, A. H., Hutchings, P. T., \& Garbutt, C. (2019). Environmental enteric dysfunction and child stunting. Nutrition Reviews, 77(4), 240253. https://doi.org/10.1093/nutrit/nuy068

Chirande, L., Charwe, D., Mbwana, H., Victor, R., Kimboka, S., Issaka, A. I., ... Agho, K. E. (2015). Determinants of stunting and severe stunting among under-fives in Tanzania: evidence from the 2010 cross-sectional household survey. BMC Pediatrics, 15, 165. https://doi.org/10.1186/s12887-015-0482-9

Dinkes, P. S. T. (2016). Profil Kesehatan Sulawesi Tenggara. Kendari.

Erwin A, A. L. (2013). Coverage And Determinants Of Exclusive Breastfeeding In Urban Slum Area At Tallo District Of Makassar City. Jurnal Majalah Kesehatan, 6(1), 44-55.

Indriyan, E., DewI, Y. L. R., \& Salimo, H. (2018). Biopsychosocial Determinants of Stunting in Children Under Five: A Path Analysis Evidence from the Border Area West Kalimantan. Journal of Maternal and Child Health, 03(02), 146-155. https://doi.org/10.26911/thejmch.2018.03.0 2.07

Jihad, J., \& Ainurafiq, la O. A. I. A. (2016). risiko faktor BBLR, riwayat ASI Eksklusif, riwayat usia pemberian MP ASI, tinggi badan ibu dan riwayat anemia ibu saat hamil terhadap kejadian stunting pada balita usia 12-24 bulan di wilayah kerja puskesmas puuwatu kota kendari 2016. JIM Kesmas, 1(3).

Kartikawati, P. R. F. (2011). Faktor yang mempengaruhi kejadian stunted growth pada anak balita di wilayah kerja puskesmas arjasa kabupaten jember. 
https://doi.org/http://dx.doi.org/10.1016/B9 78-0-7506-8774-4.50028-9

Kemenkes RI. (2017). Pusat Data dan Infomasi \& Situasi Balita Pendek (K. RI, Ed.). Jakarta.

Kemenkes RI. (2018). Profil Kesehatan Indonesia. Jakarta: Depkes RI.

Kurniasari, A. N. R. (2012). Pendapatan Keluarga, Pengetahuan, Sikap, Konsumsi Serta Status Gizi Anak Keluarga Peternak Ikan Lele (Clarias Gariepinus). Bogor: IPB.

Lestari. (2011). Hubungan Pendidikan Orang Tua Dengan Perubahan Status Stunting Dari Usia 612 Bulan Ke Usia 3-4 Tahun. Universitas Gadjah Mada.

Mamabolo, R. L., Alberts, M., Steyn, N. P., Waal, H. A. D. De \& Levitt, N. S. (2014). Prevalence and determinants of stunting and overweight in 3year-old black South African children residing in the Central Region of Limpopo Province, Prevalence and determinants of stunting and overweight in 3-year-old black South African children residi. (September 2005). https://doi.org/10.1079/PHN2005786

Martorell, R., Horta, B. L., Adair, L. S., Stein, A. D., Richter, L., Fall, C. H. D., ... Group, C. on H. O. R. in T. S. (2010). Weight gain in the first two years of life is an important predictor of schooling outcomes in pooled analyses from five birth cohorts from low- and middleincome countries. The Journal of Nutrition, 140(2), 348-354. https://doi.org/10.3945/jn.109.112300

Najahah, I. (2013). Faktor risiko balita stunting usia 12-36 bulan di Puskesmas Dasan Agung, Mataram, Provinsi Nusa Tenggara Barat. Public Health and Preventive Medicine Archive; Vol 1 No 2 (2013): Public Health and Preventive Medicine Archive.

Onis, M. De, \& Branca, F. (2016). Childhood stunting: A global perspective. Maternal and Child Nutrition, 12, 12-26. https://doi.org/10.1111/mcn.12231

Puskesmas Puuwatu. (2017). Laporan Puskesmas Puuwatu. Kendari: Seksi Data Puskesmas Puuwatu.

Rambitan, W., Purba, R. B., Kapantow, N. H., Kesehatan, F., Universitas, M., Ratulangi, S., ... Batita, A. (2014). Hubungan riwayat pemberian ASI ekslusif sebagai faktor risiko kejadian stunting pada anak batita 1-3 tahun di Wilayah Kerja Puskesmas Kecamatan Kawangkoan
Kabupaten Minahasa. 167.

UNICEF. (2013). Improving child nutrition, the achievable imperative for global progress. New York.

UNICEF, I. (2015). Laporan Tahunan. Jakarta: UNICEF: Unite For Children.

Warsini Hamam; Nurdiati, Detty Siti, K. T. H. (2016). Riwayat KEK dan anemia pada ibu hamil tidak berhubungan dengan kejadian stunting pada anak usia 6-23 bulan di Kecamatan Sedayu, Bantul, Yogyakarta. Jurnal Gizi Dan Dietetik Indonesia (Indonesian Journal of Nutrition and Dietetics), 4(1), 29-40.

Warsini, K. (2014). Hubungan Status Gizi Ibu Saat Hamil dengan Kejadian Stunting pada Anak Usia 6-23 Bulan di Kabupaten Bantul. UGM.

World Bank. (2006). Repositioning nutrition as central to development: A strategy for large scale action. World Bank Publications. 